\title{
WHO WILL BUY MY BEAUTIFUL SONGS? AN INTRODUCTION TO THE DICKINSONIAN SENTENCE IN PETER DOHERTY'S WORKS
}

\section{Marcela Santos Brigida \\ Mestranda em Literaturas de Língua Inglesa pela UERJ, Bolsista CAPES \\ E-mail: marcelascastelli@gmail.com}

\section{RESUMO}

A obra de Emily Dickinson exerce profunda influência sobre Peter Doherty. Neste artigo, estudamos como a visão de Dickinson sobre a tensão entre o artista e o mercado ressurge nos escritos do poeta inglês. A ansiedade gerada pela fama e exposição desencadeia em ambos a escolha de certos temas. Os dois rejeitam a mercantilização da obra de arte e sua transformação em peça de entretenimento. Enquanto em Dickinson isso se reflete na sua aversão à interferência editorial, na recusa de publicar seus poemas e no afastamento do meio social, Doherty aborda a tensão gerada pela fama em suas letras de música, entradas de diário e entrevistas. Lyndall Gordon (2010, p. 139) situou a ansiedade em relação à exposição como um ponto de conversão entre Dickinson e Doherty. Recorrendo à leitura cerrada e à análise comparativa, buscamos estabelecer como a influência de Dickinson se manifesta na voz contemporânea do poeta inglês.

Palavras-chave: Emily Dickinson, Intertextualidade, Poesia.

\begin{abstract}
Emily Dickinson's oeuvre had a profound influence on Peter Doherty. This paper turns to how Dickinson's approach to the tension between the artist and the marketplace resurfaces in the English poet's works. With both writers, the anxieties engendered by fame and public exposure appear to trigger the choices of certain themes and motifs. Both of them refuse the commodification of the artwork and its rendering into a piece of entertainment. While in Dickinson this appears in her aversion to editorial interference, her refusal to publish her poems and her social withdrawal, Doherty addresses the tension generated by fame in his song lyrics, journal entries and interviews. Lyndall Gordon (2010, p. 139) has posited their anxiety towards public exposure as a point of conversion between Dickinson and Doherty. Through close reading and comparative analysis, we seek to establish how Dickinson's influence appears in Doherty's contemporary voice.
\end{abstract}

Keywords: Emily Dickinson, Intertextuality, Poetry.

This paper was produced as part of an ongoing research project entitled Peter Doherty's Contemporary Take on Emily Dickinson: A Transit Between Sentences. The research 
seeks to establish in which ways Emily Dickinson's search for the dessubjectified voice of the poet - announced in "I'm Nobody! Who are you?" - resurfaces in Peter Doherty's works. Here, the writer-reader relationship is studied to gain access to the manifestations of Dickinson's influence on Doherty and instances of intertextuality. In "What Is the Contemporary?" (2006), Giorgio Agamben delineates how tradition allows us to fracture the vertebrae of chronological time to reach contemporariness with writers and texts from other times. If those who are truly contemporary "neither perfectly coincide with their times nor adjust themselves to its demands" (AGAMBEN, 2006, p. 40), the disjunction and anachronism inherent to contemporariness appear to offer a space of communication with the immemorial. In that sense, Doherty is approached as a reader who was influenced not only by Dickinson's poetic oeuvre, but also by the conceptions about art that transpire from her work. A pervasive theme in Dickinson is that of entrapment, one that she shares with Doherty. We seek to establish here how the poet's suffocation in the face of social conventions - which she mocks in "What Soft - Cherubic Creatures -" (P401) - resurfaces in her writing as an element of the Dickinsonian sentence. In A Room of One's Own (1929), Virginia Woolf presents the concept of the sentence as something that stands between the text's materiality and a verdict for identities that do not wish to be fixed by their own times (PINHO, 2015). Dickinson's sentence is explored here as one that sought to neutralize the context of Puritan nineteenth-century America to find a voice of Nobody, a voice of poetic freedom from social, political or religious constraints. In his turn, Doherty, while struggling against the pressures of the entertainment industry upon his works and himself as an artist, establishes a dialogue with tradition that allows him to respond to the question Dickinson (1960, p. 488) asks her reader: "I'm Noboby! Who are you?/ Are you - Nobody - too?" - 
and to search for a sentence that is free from the constraints of engagement and the "dreariness" of being Somebody. We argue here that, in Dickinson and Doherty, the threat of the commodification of the artwork as well as the implications of fame generate an anxiety that works as a trigger for the process of writing, getting reflected in the artwork itself. While with Dickinson this appears in her disdain towards what she calls "prose" commonplace usages of language - and in her refusal of publishing her poems, with Doherty, it manifests in his song lyrics, journal entries and interviews. This is a remarkable point of conversion between Dickinson and Doherty, evinced by their choices of themes and imagery.

Peter Doherty is an English poet, songwriter and visual artist who became known to the public in the beginning of the $21^{\text {st }}$ Century, circa 2002 . His relationship with fame, public exposure and the media is as tense as it is intricate. Emily Dickinson has exercised a complex influence on him. Doherty became aware of her poetry at an early age, and besides having mentioned her in several interviews (CRIPPS, 2004; BARTON, 2006), Dickinson appears in his journal entries that were published in an anthology entitled From Albion to ShanGri-La (2014). Her verses are cited in two of his songs: At the Flophouse (Babyshambles, Babyshambles, 2004) and Arcady (Peter Doherty, Grace/Wastelands, 2009). Lyndall Gordon (2010, p. 140), in her Emily Dickinson biography, Lives Like Loaded Guns, asserts that Doherty presents a "Dickinsonian aversion to public eyes". The perceived isolation of the American poet should be addressed with care. Critics such as Martha Nell Smith dispute the commonplace notion of Dickinson as a reclusive eccentric, seeing her attitude towards print culture as a predilection for an "alternative mode of textual reproduction and distribution" in which she could have more control over her poems: 
Smith challenges the concept of Dickinson as writing in isolation and invites the reader to reconsider the concept of "publication". Highlighting Dickinson's careful distinction between "publish" and "print," Smith regards the writer's letters and fascicles as alternative forms of publication: "her chirographic 'publication' was not simply 'part of an unusual and painful strategy that signalled privacy and alienation' but was instead a consciously designed alternative mode of textual reproduction and distribution" which would guarantee Dickinson independence of the limitations imposed by mechanical modes of production on features such as calligraphy or punctuation (I-2). (MESSMER, 1998, p. 320).

Dickinson's withdrawal appears here as a powerful stance of the poet's rejection of the book trade. If we interpret her refusal to publish as a stance of resistance against the standardization of her work, we can easily establish a connection between this aspect of Dickinson's performance and Doherty's tense relationship with the public arena of the music industry. His comparison of performing live to "war", and writing alone and in silence to "a dream" led Gordon (2010, p. 140) to define him as "Dickinsonian". Questioned whether he thought it was currently possible for a person to make a living as a poet, Doherty replied by addressing the option of turning to performance poetry, a practice he classed as artificial:

I tried to do it for a little while, putting on a show and building up this thing, this character that I built on stage, but in the end, I got driven to the music which became, I wouldn't say easier, but you've got such a more powerful way of putting out a message and reaping the benefits that a young man needs. Like this weird craving for fame that you had when you were younger and regretting that really when it comes to trying to do something, like you say, that is just poetry pure and simple on a page. (ATTISSO, 2016, p. 52).

In Doherty's words, the stage and the artifice required to perform on it are opposed to the artist's will. Further, in the same interview, he defines writing poetry without the necessity of promoting it as "the ideal". The act of putting an end to a creative effort - with the purpose of entertaining an audience, for instance - already implies a concession. In the 
opposition he establishes between writing and performing live, Doherty echoes his earlier comparison of performing on stage to war and writing in silence to a dream. The idyllic imagery persists on the poet's vocabulary as he states, "reading is the most luxurious thing in the world. Literature is the stuff dreams are made of..." (ATTISSO, 2016, p. 54). Under the light of Doherty's views on the constrictions inherent to the stage experience versus the creative freedom of poets and readers, we turn to the lyrics of his song "Gang of Gin" (never officially released, the song was leaked online in 2004), where he addresses the frustration of being expelled from his own band. Besides being highly critical of the musical industry, he denounces that promises of fame and recognition come with restrictions, hinting at violence: "In this industry of fools/ Musclemen and ghouls". It is also expected that the artist will relinquish his own will to work as a pawn to promote other people's interests: "If you're not a puppet or a muppet/ Then you might as well call it a day". Doherty then denounces the hypocrisy that surrounds the structure comprised and promoted by the music business. It was supposedly due to his drug use that he stopped being allowed to play in the band. This stanza questions the legitimacy of those claims: "The truth here gets distorted/ The wall scrapings get snorted/ I'm welcome back if I give up crack/ But you gave me my first pipe anyway". In the middle eight, he asks: "Who will buy my beautiful roses?/ Who will buy my beautiful songs?". Those verses are thought-provoking not only because they paraphrase the song "Who Will Buy?" (Lionel Bart) from the musical Oliver! (1960), an adaptation of Charles Dickens' Oliver Twist (1837-39), but also because they can be tied to issues addressed on his Poetry Corner Paris interview. In the interlude offered by the middle eight, Doherty conveys the image of the artist trying to sell his work, but doing so to survive, making the same plea of the rose-seller in the musical. In the scene in question, Oliver is out on an errand for Mr. 
Brownlow when he sees the vendors offering their goods and joins them in song. After they leave, he is grabbed by Bill and Nancy and taken back to Fagin. There lies a clever analogy from Doherty: the artist, unaware of the risks of making himself vulnerable out on the marketplace, is seized by corrupt figures with questionable intentions who render him powerless. In his denunciation of a vicious system in which he got caught up as an artist looking for recognition as well as in his suggestion that he had subjected himself to it for the need to make a living out of his art, Doherty echoes Dickinson's harsh criticism of the book trade in her poem 709. There, it is argued that "Publication - is the Auction/ Of the Mind of Man -/ Poverty - be justifying/ For so foul a thing". Dickinson's speaker presents poetic genius as a divine gift that should not be sold by the poet, who is only its bearer, not its owner. Dickinson appears here as a poet caught up between Romanticism and Modernism; while her idea of the poet as a bearer is romantic, the poem is modern in its form. Josef Raab has addressed this quality of her metapoetic commentary on "The Metapoetic Element in Dickinson":

With regard to her place in literary history, Dickinson's metapoetic comments will allow us to position her as a protomodernist. While she is often classified as a romantic poet, a closer examination of her poems on poetry reveals that, although she sometimes seems to adhere to Wordsworth's idea of poetry as the "spontaneous overflow of powerful feelings" or Coleridge's organicist thought and although she sees the role of the poet primarily in romantic terms, Dickinson is also a precursor of the modernists. What she seeks to achieve in poetry is to render the indeterminate meaning of the world and of human existence. Since unambiguous truth no longer exists, language, in her opinion, cannot get to the center of objects or issues. (RAAB, 1998, p. 274).

The last stanza of the poem, "In the Parcel - Be the Merchant/ Of the Heavenly Grace -/ But reduce no Human Spirit/ To Disgrace of Price - " brings an ingenious employment of 
mercantile imagery that is also seen in "I took one Draught of Life - ". While the poet can be the "merchant of heavenly grace" and the poem a parcel, the artist should never put a price at the human spirit. She turns to the theme of poverty from the first stanza: while it makes the foul commodification of the artwork justifiable, price is still a disgrace that should not be imposed upon art.

Addressing Dickinsonian poetics in "Searching for Dickinson's Themes", David Porter speaks of the difficulties of identifying predominant themes in Dickinson's oeuvre. While “other major American poets of Dickinson's time induce full and coherent thematic understanding in their persistent readers", he states, "with Dickinson, our impassioned search for a similar thematic preoccupation leads to a formidable array of mysteries concerning her intellectual focus and her intentions" (PORTER, 1998, p. 183). According to the critic, that aspect of Dickinson's writing makes it impossible for the reader to remain passive. Since most of her poems resist fixed interpretation, Dickinson activates "unbridled reader-response free play" (PORTER, 1998, p. 188). By choosing ambiguity over fixed meanings, the poet writes in a manner that obliges the reader to write along with her, whether by completing her verse where she leaves intentional gaps, or, as Doherty has done, by adapting her poems and becoming inspired to the point of writing in an equally ambiguous manner.

Doherty's references to Dickinson in interviews present his relationship with the writer as an escape from a restrictive reality. In an interview for The Independent, Doherty traced his interest in Dickinson's poetry back to his childhood, associating her with his creative inwardness: "I had no choice really but to disappear into myself, just veering between old, 
flickery episodes of Rising Damp, Tony Hancock radio shows, Emily Dickinson, flowers and QPR" (CRIPPS, 2004). In a later interview for The Guardian, Doherty spoke of his song "At the Flophouse", saying that he "nicked one of two of her [Dickinson's] lines", later stating that he once "nicked an Emily Dickinson book" from school:

When I was a kid we were always moving around, changing schools and I remember winding up in the Nicholas Chamberlaine comprehensive in Bedford, and I just stood up one day in class and it was like, 'Doherty! Doherty! What you doing? Sit down!' And I just walked out, up through the estate, up the hill, and just sat in the cemetery. Sat there for hours. And I think I'd nicked an Emily Dickinson book." He drifts into quietness again. "I think she had quite a curious life as well. Not like ... more abstinence, wasn't it?" (BARTON, 2006).

Doherty's choice of words here should not be overlooked. The writer weaves images that associate his relationship with Dickinson's poetry to acts of transgression that allowed him to escape the roles traditionally assigned to a young English boy: the refusal upon the teacher's orders for him to sit down, the literal escape from school grounds and the "nicking". It is literal when regarding a book, and poetic in the allusion made to Dickinson's poem in the lyrics of "At the Flophouse". Finally, when showing an interest in the poet's biography, Doherty draws a possible comparison with his own, hinting at a sense of identification with her. In the same way that pop culture has bestowed an "eccentric poetess" persona upon Emily Dickinson, the media has given epithets to Doherty ranging from "enfant terrible" to "rebellious musician". Doherty rejects such titles, as shown by his Channel 4 interview with Krishnan Guru-Murthy, in which he vehemently refused being called a rockstar, arguing that he sees the term as offensive. Questioned as to how he would like to be addressed, he replied with his own name (CHANNEL 4 NEWS, 2016). In a 2009 interview for NME magazine on the release of his first solo album, Doherty was asked about 
the reason behind his choice of the name "Peter Doherty" to promote the album, suggesting he had changed his name since he had been mainly addressed and referred to by the media as "Pete Doherty" until then. The composer denied that he had changed anything at all. According to him, from his earlier days of media exposure as a member of The Libertines, he had presented himself as Peter:

I've never changed my name, you lot changed my name. In the very first interview I ever did with NME and I remember it well because it was in the day of the May Day riots. I said: "Can you put 'Peter'?" and the geezer looked me in the eye and said: "Yeah, I'll put Peter, whatever." Pete. And I wrote in: "Dear NME, right, look: my name is Peter, please can you put Peter? Yours sincerely, Peter." Next week, "Pete eats hotel room" or something and so it has continued, you know? And now you've decided I'm Peter, and it's like: “Have you changed your name?" (...) I've always been Peter. (...) I've always said that. It's just that they've changed it to market me as Peter. (NME, 2009).

There is a hint of scepticism in the way Doherty tells the interviewer that it was "their" choice to market him as Peter. By denying that he had anything to do with the shift from Pete to Peter, he shows that neither he or his work had been altered in any way by it. The artist seems unimpressed by the choice of the name under which his album would be released as it was not up to him in any form. The shift appears as a marketing tool from an industry that sells or markets art as it wishes. Whatever image they choose to promote cannot reflect the artist. Aligning his refusal of media-given titles with his criticism on the objectification of the artist, it is interesting to think of the way Doherty works Dickinson's poem "I took one Draught of Life - " into his own language. While she builds an opposition between countable, material aspects and the value of being - of existence - to reach the intangible "Dram of Heaven", Doherty's speaker affirms that after paying the "market price" for the "draught of life" he took, he finds himself "estranged", alienated: the poet becomes a 
stranger to the world that tries to impose an objective value upon him. This disjunction is illustrated by the fact that Doherty had always been ignored while presenting himself as Peter, but when a record label marketed him that way, he was questioned about the reasons behind "changing" his name. "At the Flophouse" appears as an interesting instance of intertextuality between Dickinson and Doherty, showing the artist caught up between a public image he rejects and the search for a poetic voice free from the constraints imposed on him by his immediate context, as Dickinson had done before him by presenting herself as Nobody. In their dynamic dialogue, Doherty appears as a possible fit for Dickinson's other, contemporary Nobody, whom the Poet of Amherst addresses in her poem.

On What is Literature, Jean-Paul Sartre (1988 [1948], p. 28) asserts that poetry would be "on the side of painting, sculpture, and music", while prose would be on the realm of establishing signification and engagement. Poets are perceived as "men who refuse to utilize language" (SARTRE, 1988, p. 12). The French critic's views are in tune with Dickinson's refusal to alter the way in which she wrote in order to conform to the expectations of editors and the reading public of her time. It is not poetry's business to please. To Dickinson, it does not belong a realm of utility and should not be written with the intent of selling newspapers or books. The fact Dickinson did not title her poems has been addressed by John Mulvihill as a stance of her disinterest in publication. In "Why Dickinson Didn't Title" he says that the "innovation of providing titles for short poems grew out of the commercialization of poetry. Poems are given titles when they are intended for public consumption" (MULVIHILL, 1996). Therefore, “Dickinson's nontitling strongly suggests she never had any interest in publishing" (MULVIHILL, 1996, p. 15). The choice of the manuscript over print in Dickinson's poetic oeuvre also speaks of the idea she made of the writer-reader relationship. The book 
trade, as Lyndall Gordon (2010, p. 141) tells us, should not infect it: "Dashes, pushing the language apart, create spaces for readers to fill. To join with her can give an ordinary mind an amazing surge. Print culture, by contrast, renders the reader more passive, an inert receptacle for the book trade". Dickinson chose her readers carefully. She told Susan Gilbert in a letter they were "the only poets" and everyone else was "prose" (L I:56). Besides being her friend - and later sister-in-law -, Gilbert was perhaps Dickinson's main reader during the poet's lifetime, receiving many poems and letters throughout the years (MARTIN, 2002, p. 83; GORDON, 2010, p. 151). In the first editions of her published works, editors would try to warn readers of Dickinson's unconventionality as well as to polish her verse (MILLER, 1998, p. 241), a practice the poet would have undoubtedly not authorized. When she wrote to Higginson, she never asked him to help her standardize her writing, but to let her know if her verse was "alive" (L260). In a letter sent about two months later, in June 1862, Dickinson also told him she had no intention to publish, stating she had "smiled" at his suggestion that she would put off any intentions to seek publication of her poems, stating that such an intent was "foreign to her thought, as Firmament to Fin" (L265). She then asserts that her "Barefoot-Rank" is better than the pursuit or even the attainment of fame. Dickinson's poems are so appealing to a reader such as Doherty precisely because they invite the person who reads her poetry - someone who could be Nobody too - to be creative for the sake of it.

The way in which Dickinson shuns the adjoining concepts of publication and fame in her writing still sounds contemporary. The poet anticipated an issue that would be addressed by literary theorists and critics of the $20^{\text {th }}$ century, especially in the Frankfurt School: the artwork as a commodity. Doherty's aversion to public exposure has been 
approached here as a Dickinsonian trait. We can think of this shared aspect of the artists' performances under the light of Theodor Adorno's Aesthetic Theory (1970). To the German theorist, the more an artwork is understood, the less it can be concretely enjoyed (ADORNO, 1997 , p. 13). The bourgeois conception of the artwork as an object made for the public's enjoyment appears a failed construct that prevents the admiration of the work's existence in itself, begetting the illusion it comes to be for the sake of the observer. In a 2017 interview, Doherty stated that he hates it when, before a concert, someone tells him to "have fun" (BLUE BALLS FESTIVAL, 2017). Adorno (1997, p. 13) has addressed this uneasiness stating that "for him who has a genuine relation to art, in which he himself vanishes, art is not an object; deprivation of art would be unbearable for him, yet he does not consider individual works sources of joy". In an interview included in his book From Albion to Shangri-La (2014), Doherty remarks on how he seems to have spent a lot of his creative time contradicting himself, "searching for liberty" whilst imprisoning himself. He goes on to say that the "process of creativity rejuvenates the spirit, it justifies existence; having a couple of songs on the go, that's fulfilment to me, that's when the soul is healed" (DOHERTY, 2014, p. 240). Under the light of his metaphorical construction of the stage as a cage in the song "Killamangiro", it is arguable that while he searches for freedom through poiesis, the demands attached to make a living out of his music bring on a sense of entrapment. In one of the journal entries included in the same book, the artist expresses his aversion to the commitments inherent to a career in the music business and his yearning for more freedom. Speaking of the "extremely pleasant feeling that comes with splendid isolation", he declares: "Love it when there are no engagements, gigs, responsibilities, anything. Only the blank covers of the morning, evening, afternoon" (DOHERTY, 2014, p. 26). Dickinson could "select 
her own society" then "shut the door" (DOHERTY, 2014, p. 303), but the uneasiness that stems from outward pressures gains expression in the recurrence of the theme of entrapment in her poems and letters. Some critics have revised theories about Dickinson's "withdrawal from the world" to interpret her behaviour as commitment to her craft. Adrienne Rich, for instance, posits the poet's withdrawal as "a deliberate choice in her commitment to writing. Dickinson thus emerges as a woman who "had it out on her own premises" (MESSMER, 1998, p. 310). In his career as a musician, Doherty cannot avoid the exposure that brings him anxiety. If we look at his interview for Poetry Corner Paris, it becomes clear that performing in public was an issue even when it was as a poet that he took the stage. On his Blue Balls Festival interview, Doherty asserts twice that in the moments that precede going onstage he feels he would rather be anywhere else. The lyrics to his song "Killamangiro" (Babyshambles, Down in Albion, 2005) might then be read as the artist's questioning of the nature of our relationship with art. Doherty's speaker appears to question our need for an artifice to mediate our aesthetic experience as he asks why "would you pay to see me in a cage/ some men call the stage". The freedom the artistic endeavour offers him becomes clouded by the anxiety provoked by performing before an audience that expects to be entertained. Doherty has also stated that he can feel his "head disappear" when onstage (BLUE BALLS FESTIVAL, 2017), suggesting a withdrawal from the outside world into the subjective creative space of the poet. Doherty escapes his public image and the tension it brings him by "shutting the door" in his own way.

The conflict between inwardness and social expectations triggers a sense of entrapment that resurfaces in Dickinson's and Doherty's works not only through themes and imagery, but as a core element of their poetic projects. Evading commodification and 
refusing to allow art to be stripped of its autonomy by the market's greedy demands appears as a major question for both in poems and lyrics as well as in letters and journal entries. The sense of poetic nobodyness Dickinson evokes in her poem 488 is manifested throughout her oeuvre, not only through what she writes, but also in the way she writes it. The same can be said about Doherty, who establishes dialogues with tradition to construct meaning through intertextuality. His collected writings are an endless dialogue between reader and writers: one can only understand it by joining in. Doherty's rejection of the word "fun" to describe going onstage is also a reflection of how he stands as an artist. The requirement to entertain an audience does not suit him as a writer as much as publication and fame did not suit Emily Dickinson. The intertwining of the concept of the celebrity with that of the artist begets a chaos where the latter is going to suffer from the confrontation with the "fetishistic idea of the artwork as property that can be possessed and destroyed by reflection" (ADORNO, 1997, p. 13). Dickinson could not bear the idea of her poems being turned into exploitable property. The way in which the entertainment industry explores Doherty is even more overbearing than what the Poet of Amherst might have anticipated. Not only is the artwork commodified, but the image of the artist is handled and marketed as a product as well. One could argue that the same has happened to Emily Dickinson and her works, but only after her death, when others took it upon themselves to speak as promoters of the Dickinsonian legacy. The issue of how we can approach art without appropriating it in a manner that reduces it to exploitable property is central to the discussion proposed here. It remains as contemporary to us as Dickinson's verse to Doherty's writing.

\section{REFERÊNCIAS}


ADORNO, Theodor W. Aesthetic theory [1970]. London: A\&C Black, 1997.

AGAMBEN, Giorgio. "What is the Contemporary?". In: What is an apparatus? And other essays, p. 39-54, Stanford: Stanford University Press, 2009.

ATTISSO, Larry. "Peter Doherty: Le Poéte Ultime". In: Poetry Corner Paris. Paris: PCP, 2016. p. 48-65.

BARTON, Laura; PETRIDIS, Alexis. "'Emily Dickinson? She's hardcore'”. 2006. Available at: <https://goo.gl/Az2oSz> Accessed on: 21 May 2018.

BLUE BALLS FESTIVAL. "Blue Balls Festival 'Meet The Artists': Peter Doherty". 2017. Available at: < https://www.youtube.com/watch?v=0TaE9ias47g>. Accessed on 13 May 2018.

CHANNEL 4 NEWS. "Pete Doherty speaks to Krishnan Guru-Murthy". Available at: < https://www.youtube.com/watch?v=HYk5j-4uoCM>. Accessed on 13 May 2018.

CRIPPS, Charlotte. "Pete Doherty: the boy who fell to Earth". 2004. Available at: <https://goo.gl/D7ESqY> Accessed on 12 May 2018.

DICKINSON, Emily. Emily Dickinson Letters. London: Everyman's Library, 2011.

DICKINSON, Emily. The Complete Poems of Emily Dickinson. Boston: Little, Brown \& Company, 1960.

DOHERTY, Peter. From Albion to Shangri-La. London: Thin Man Press, 2014.

ELIOT, Thomas S. "Tradition and The Individual Talent" [1919]. Perspecta, v. 19, p. 36-42, 1982.

GORDON, Lyndall. Lives Like Loaded Guns: Emily Dickinson and Her Family's Feuds. Nova York: Penguin, 2010.

MARTIN, Wendy (Ed.). The Cambridge Companion to Emily Dickinson. Cambridge: Cambridge University Press, 2002.

MESSMER, Marietta. “Dickinson's Critical Reception". In: MILLER, C.; HAGENBÜCHLE, R.; GRABHER, G. M. (Ed.) The Emily Dickinson Handbook. Massachusetts: University of Massachusetts Press, 1998. p. 299-322.

MILLER, Cristanne. "Dickinson's Experiments in Language". In: MILLER, C.; HAGENBÜCHLE, R.; GRABHER, G. M. (Ed.) The Emily Dickinson Handbook. Massachusetts: University of Massachusetts Press, 1998. p. 240-57.

MULVIHILL, John. "Why Dickinson didn't title". The Emily Dickinson Journal, v. 5, n. 1, p. 7187, 1996.

NME. "Pete Doherty interview with NME Radio - Part One" [2009]. Available at: <https://youtu.be/7nfofx08Yd4> Accessed on 20 May 2018. 
PINHO, Davi. Imagens do Feminino na Obra e Vida de Virginia Woolf. Curitiba: Appris, 2015. PORTER, David. Searching for Dickinson's Themes. In: MILLER, C.; HAGENBÜCHLE, R.; GRABHER, G. M. (Ed.) The Emily Dickinson Handbook. Massachusetts: University of Massachusetts Press, 1998. p. 183-96.

RAAB, Joseph. The metapoetic element in Dickinson. In: MILLER, C.; HAGENBÜCHLE, R.; GRABHER, G. M. (Ed.) The Emily Dickinson Handbook. Massachusetts: University of Massachusetts Press, 1998. p. 273-95.

SARTRE, Jean-Paul. "What is literature?" and other essays [1948]. Cambridge: Harvard University Press, 1988.

Artigo recebido em: 30 de maio de 2018. Artigo aprovado em: 19 de agosto de 2018. 